J. Clin. Chem. Clin. Biochem.

Vol. 27, 1989, pp. 803-806

(C) 1989 Walter de Gruyter \& Co. Berlin - New York

\title{
Sound Speed, Density and Total Protein Concentration of Blood ${ }^{1}$ )
}

\author{
By D. Schneditz \\ Physiologisches Institut der Universität Graz
}

$H$. Heimel and $H$. Stabinger

Labor für Meßtechnik Dr. H. Stabinger, Graz

(Received March 16/July 11, 1989)

\begin{abstract}
Summary: The sound speed and the density of a series of blood samples was measured in a temperature range from $20^{\circ} \mathrm{C}$ to $40^{\circ} \mathrm{C}$. An expression was derived from a least square fit which related the sound speed in human blood in this temperature range to the blood density and to the total protein concentration, respectively. The data were obtained from the measurement of sound speed and density by means of a newly developed Density and Sound Analyzer (DSA-48, A. Paar K. G., 8054 Graz, Austria). The relationship of sound speed, density and temperature permits the calculation of the total protein concentration with an accuracy of $1 \mathrm{~g} / \mathrm{kg}$. The resolution of the measurement is in the order of $0.1 \mathrm{~g} / \mathrm{kg}$.
\end{abstract}

\section{Introduction}

The concentration of the red blood cells and of the blood proteins is of general interest to the physician. First, it is of importance in the evaluation of the blood picture. Most methods were developed for single point measurements and the results therefore reveal a static view of the concentrations under investigation.

More than ten years ago, a method which extended the concentration measurement to the continuous evaluation of haematocrit and total protein concentration was successfully introduced for the investigation of body fluid dynamics $(1,2)$. The method was based upon the continuous measurement of blood dènsity (Q). But since the measuring system was neither designed for single use nor for in vivo applications, the field of investigations was restricted to a

1) This work was in part supported by the Austrian Fonds zur Förderung der Wissenschaftlichen Forschung by grants to the project P6616. few thoroughly controlled experimental studies. However, it was soon recognized by different working groups that blood density monitoring was of special value for investigating fluid dynamics both in separate organs $(3-5)$ and in the organism as a whole $(6,7)$.

However, the main drawback remained, i.e. that the measuring system was not able to use disposable cells and that the material of the cell had a poor biocompatibility. To overcome this drawback, a new method was recently introduced for monitoring the concentration of blood constituents in perfused and disposable polymer tubes (8). The method is based upon the measurement of the sound speed (v). Sound speed is not a very familiar quantity in clinical chemistry and it is necessary to present an expression which relates the sound speed of blood to blood density, and in consequence, to total protein concentration. With this relation, which holds for a temperature range from $20^{\circ} \mathrm{C}$ to $40^{\circ} \mathrm{C}$, it is possible to convert sound speeds in blood into corresponding densities and total protein concentrations. 


\section{Materials and Methods}

Whole blood was obtained from healthy volunteers by venipuncture. It was anticoagulated with EDTA-K $\mathrm{K}_{2}(1 \mathrm{~g} / 1 \mathrm{blood})$. All measurements were carried out within 36 hours. To produce samples with different total protein concentrations the blood was centrifuged ( $15 \mathrm{~min}$ at $3500 \mathrm{~g}$ relative centrifugal force) and the separated phases, the red blood cell concentrate and the supernatant plasma were mixed in appropriate proportions.

The measurements were made with an automatic Density and Sound Analyzer (DSA-48, A. Paar K. G., 8054 Graz, Austria). Detailed descriptions of the principle of the density measurement and of the sound speed measurement may be found elsewhere $(8,9)$. The sample volume of the measuring system was $2 \mathrm{ml}$, and the temperature of the sample was controlled to $\pm 0.01^{\circ} \mathrm{C}$ by an internal Peltièr thermostat. The accuracy of both the density and the sound speed measurement was $1 \cdot 10^{-4}$ of the reading, the resolution was $1 \cdot 10^{-5}$. The measuring system was controlled by an external computer which permitted automatic temperature setting and data acquisition.

Densities and sound speeds were measured in $1^{\circ} \mathrm{C}$ steps in a temperature range from $20^{\circ} \mathrm{C}$ to $40^{\circ} \mathrm{C}$. Temperature profiles were carried out by cooling the samples down from $40^{\circ} \mathrm{C}$. This procedure avoids the formation of gas bubbles which interfere with the measurement. Scanning the density and the sound speed of a blood sample in this temperature range is quite time consuming. In order to avoid red blood cell sedimentation and phase separation during the measurement the blood samples were homogenized by sonication ( $5 \mathrm{~min}$ at $100 \mathrm{~W}$, cooling). It was previously shown that this treatment did not alter the density readings (10), and there was no systematic difference between the sound speeds of whole and sonicated blood samples.

\section{Total protein concentration}

Total protein concentration is the sum of the plasma protein concentration $\left(c_{\text {plasma }}\right)$ and of the mean cellular haemoglobin concentration (MCHC) weighted by the volume fraction of the component (10):

$\mathrm{TPC}=\mathrm{MCHC} \cdot \mathrm{hct}+\mathrm{c}_{\text {plasma }} \cdot(1-\mathrm{hct})$,

where TPC $=$ total protein concentration, hct $=$ haematocrit.

Total protein concentration is usually given in the unit of $g / l$, but since this unit is dependent on temperature due to the thermal expansion of the sample, it is more convenient for present purposes to use the unit $\mathrm{g} / \mathrm{kg}$. The transformation from the common unit $\left(\mathrm{g} / \mathrm{dm}^{3}\right)$ to $\mathrm{g} / \mathrm{kg}$ is made according to the following relation:

TPC (in $\mathrm{g} / \mathrm{kg})=1000 \cdot \mathrm{TPC}\left(\right.$ in $\left.\mathrm{g} / \mathrm{dm}^{3}\right) / \mathrm{Q}\left(\right.$ in $\left.\mathrm{g} / \mathrm{dm}^{3}\right)$.

The total protein concentration (given in $\mathrm{g} / \mathrm{kg}$ ) of a blood sample is the same at any temperature.

\section{Data analysis}

The significance of the results was ascertained by fitting the data $(z)$ to polynomial functions for two $(x, y)$ independent variables according to the method of least squares. The fits are of the type

$z_{\text {fit }}=\Sigma a_{i} \cdot x^{r} \cdot y^{g}$

where $f$ and $g$ range from 0 to 2 alternately.

\section{Results and Discussion}

Sound speed and density were measured in isotonic saline (total protein concentration $0 \mathrm{~g} / \mathrm{kg}$ ), in plasma samples (total protein concentration approximately $70 \mathrm{~g} / \mathrm{kg}$ ), in blood samples with different haematocrits and in red blood cell concentrates (total protein concentration up to $300 \mathrm{~g} / \mathrm{kg}$ ). The temperature range was $20^{\circ} \mathrm{C}$ to $40^{\circ} \mathrm{C}$. The dependence of blood density onsoundspeed and temperatureisshowninfigure 1.

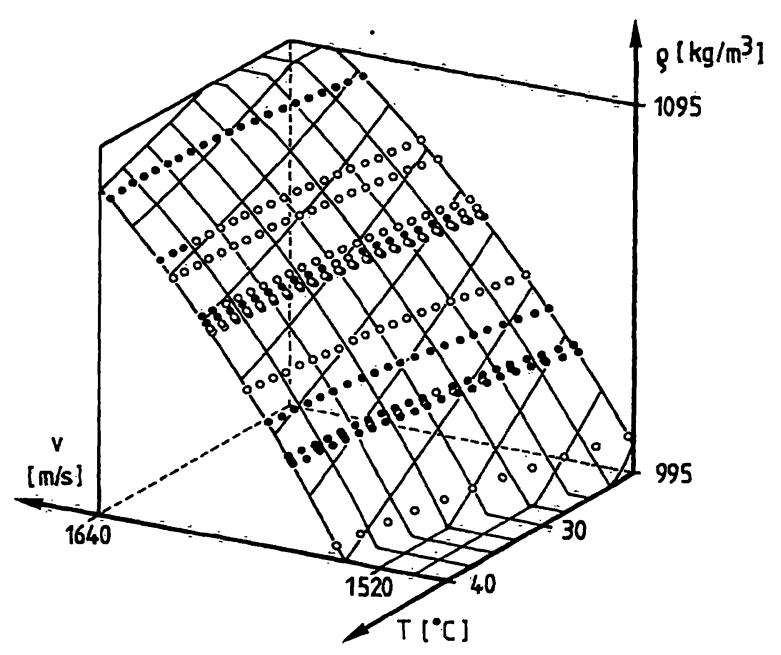

Fig. 1. Sound speed, density and temperature of blood. The relation between blood density (Q), sound speed (v) and temperature $(\mathrm{T})$ of 12 blood samples with different total protein concentration and of isotonic saline solution is shown in a three-dimensional plot. Data points are given in open and closed symbols depending on whether they lie behind or in front of the plane which is calculated from at least squares fit to a second order polynomial for two independent variables (see equation 3 in the text).

The data were fitted to a polynomial (see equation 3 ), density being the dependent variable and sound speed and temperature being the independent variables. The coefficients for the fit are given in table 1 (column 1). This relation permits the calculation of the density of a blood sample - at a given temperature - from the measurement of sound speed at this specified temperature. However, a change of sample temperature will also change the density (and the sound speed) of the same blood sample.

Density itself is related to total protein concentration. The relationship for the calculation of the total protein concentration from sample densities was obtained from the linear fit of data, determined by Hinghofer et al. (10). At $20^{\circ} \mathrm{C}$ the reference between density and total protein concentration is

TPC (in $\mathrm{g} / \mathrm{kg})=3.45866 \mathrm{e}\left(\right.$ in $\left.\mathrm{g} / \mathrm{dm}^{3}\right)-3474.3$

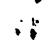

J. Clin. Chem. Clin. Biochem. / Vol. 27, 1989 / No. 10 
Tab. 1. Least squares data fit. Values of densities (e) and total protein concentrations (TPC) are fitted to a polynomial $\left(z_{\text {fit }}=\Sigma a_{i} \cdot x^{8} \cdot y^{8}\right.$, see equation 3$)$ for variable sound speeds (v) and temperatures $(T)$ according to the method of the least squares, where $a_{1}$ through $a_{9}$ are the constants, $f$ is the exponent for sound speed and $g$ is the exponent for temperature, respectively. The standard error of the stimate is given (s.e.).

\begin{tabular}{lllll}
\hline$z_{\text {fit }}$ & $\begin{array}{l}\mathrm{e}\left[\mathrm{g} / \mathrm{dm}^{3}\right] \\
\mathrm{v}\end{array}$ & $\begin{array}{l}\mathrm{TPC}[\mathrm{g} / \mathrm{kg}] \\
\mathrm{v}[\mathrm{m} / \mathrm{s}]\end{array}$ & $\mathrm{f}$ & $\mathrm{g}$ \\
$\mathrm{y}$ & $\mathrm{T}\left[{ }^{\circ} \mathrm{C}\right]$ & $\mathrm{T}\left[{ }^{\circ} \mathrm{C}\right]$ & & \\
\hline $\mathrm{a}_{1}$ & $-4.055 \cdot 10^{3}$ & $-1.6958 \cdot 10^{3}$ & 0 & 0 \\
$\mathrm{a}_{2}$ & 2.2298 & -6.6615 & 0 & 1 \\
$\mathrm{a}_{3}$ & -1.83 & -7.1317 & 0 & 2 \\
$\mathrm{a}_{4}$ & 6.1664 & $2.0626 \cdot 10^{1}$ & 1 & 0 \\
$\mathrm{a}_{5}$ & $-1.7136 \cdot 10^{-2}$ & $-3.9517 \cdot 10^{-2}$ & 1 & 1 \\
$\mathrm{a}_{6}$ & $2.2911 \cdot 10^{-3}$ & $8.8969 \cdot 10^{-3}$ & 1 & 2 \\
$\mathrm{a}_{7}$ & $-1.8334 \cdot 10^{-6}$ & $-6.1199 \cdot 10^{-3}$ & 2 & 0 \\
$\mathrm{a}_{8}$ & $9.1777 \cdot 10^{-6}$ & $2.5247 \cdot 10^{-5}$ & 2 & 1 \\
$\mathrm{a}_{9}$ & $-7.1497 \cdot 10^{-7}$ & $-2.7632 \cdot 10^{-6}$ & 2 & 2 \\
& & 1.27 & & \\
s. e. & 0.352 & & & \\
\hline
\end{tabular}

The correlation coefficient for the linear regression is 0.9994 .

Conversion of densities into total protein concentrations and the fit of the dependent variables, sound speed and temperature, to the new independent variable, total protein concentration, gives an expression which permits the calculation of the total protein concentration from the measurement of sound speed and temperature. The values for the fit are given in table 1 (column 2). The standard error of the estimate for the determination of total protein concentration is in the range of $1 \mathrm{~g} / \mathrm{kg}$. The resolution when monitoring relative changes is better by one order of magnitude.

From previous experiments it is well known that the sound speed in blood is closely related to total protein

\section{References}

1. Kenner, T., Leopold, H. \& Hinghofer-Szalkay, H. (1977) The continuous high-precision measurement of the density of flowing blood. Pflügers Arch. 370, 25-29.

2. Kenner, T. (1982) Physiological Measurement in Circulation Research; A Review on the Biological Application of a New Method. Med. Progress Technol. 9, 67-74.

3. Kenner, T., Moser, M. \& Mohl, W. (1985) Arteriovenous Difference of the Blood Density in the Coronary Circulation. Transactions Am. Soc. Mech. Eng. 34, 34-40.

4. Kenner, T., Moser, M., Hinghofer-Szalkay, H. \& Mohl, W. (1984) Indirect Determination of Fluid Filtration and Reabsorption in the Microcirculation of the Myocardium. Biomed. Tech. 29, 108-116.

5. Gamas, L. \& Lee, J. S. (1986) Density Indicator Method to Measure Pulmonary Blood Flows. J. Appl. Physiol. 60, $327-334$. concentration as well as to the haematocrit $(11-14)$. However, the measuring systems in these investigations made it difficult either to attain the high resolution of $0.1 \mathrm{~g} / \mathrm{kg}$, or to make use of disposable measuring cells which use small sample volumes. The non-linear dependence of sound speed on the haematocrit (and hence on total protein concentration, see also equation 1) was only recently reported by Collings et al. (14).

From the results it can be seen that sound speed is a convenient measure of the total protein concentration. In comparison with blood density measurements, the following differences have to be noted.

In contrast to the linear dependence between density and total protein concentration (see equation 4) the relation between sound speed and total protein concentration is not linear (quadratic terms with respect to sound speed, see table 1, column 2).

The temperature dependence is higher for sound speed than for density by approximately one order of magnitude (see fig. 1). The temperature coefficient for density $(\partial \mathrm{Q} / \partial \mathrm{T} \cdot 1 / \mathrm{Q})$ is about $-3 \cdot 10^{-4} / \mathrm{K}(10)$, that of sound speed $(\partial \mathrm{v} / \partial \mathrm{T} \cdot 1 / \mathrm{v})$ is about $1 \cdot 10^{-3} / \mathrm{K}(8$, 12-14).

These drawbacks are minor and negligible when the biomedical and clinical applicability of the new measuring technique is considered. The design of disposable and more biocompatible measuring cells (8) would permit the introduction of a high resolution concentration sensor for blood monitoring, which could be of interest especially in critical care and in the control of haemodialysis and haemofiltration. For this reason, the determination of sound speed and the relation between sound speed and total protein concentration promises to attract further interest.

6. Holzer, H., Pogglitsch, H., Hinghofer-Szalkay, H., Kenner, T., Leopold, H. \& Passath, A. (1979) Continuous Determination of the Blood Density During Hemodialysis. Wiener Klin. Wochenschr. 91, 762-765.

7. Kenner, T., Hinghofer-Szalkay, H., Leopold, H. \& Pogglitsch, $H$. (1977) The Relation between the Density of Blood and the Arterial Pressure in Animal Experiments and in Patients During Hemodialysis. Z. Kardiol. 66, 399401.

8. Schneditz, D., Heimel, H., Stabinger, H. \& Kenner, T. (1989) A sound speed sensor for the measurement of total protein concentration in disposable, blood perfused tubes. J. Acoust. Soc. Am., accepted for publication.

9. Kratky, O., Leopold, H. \& Stabinger, H. (1969) Dichtemessung an Flüssigkeiten und Gasen auf $10^{-6} \mathrm{~g} / \mathrm{cm}^{3}$ bei $0.6 \mathrm{~cm}^{3}$ Präparatvolumen. Z. Angew. Physik 27, 273-277. 
10. Hinghofer-Szalkay, H., Leopold, H., Kenner, T. \& Holzer, H. (1980) On the Coefficient of Thermal Expansion of Blood and its Constituents. Biomed. Tech. 25, 151-157.

11. Urick, R. J. (1947) A Sound Velocity Method for Determining the Compressibility of Finely Divided Substances. J. Appl. Phys. 18, 983-987.

12. Bakke, T., Gytre, T., Haagensen, A. \& Giezendanner, L. (1975) Ultrasonic Measurement of Sound Velocity in Whole Blood. Scand. J. Clin. Lab. Invest. 35, 473-478.
13. Bradley, E. L. \& Sacerio, J. (1972) The Velocity of Ultrasound in Human Blood under Varying Physiologic Parameters. J. Surg. Res. 12, 290-297.

14. Collings, A. F. \& Bajenov, N. (1987) Temperature dependence of the velocity of sound in human blood and blood components. Australas. Phys. Eng. Sci. Med. 10, 123-127.

Dr. Daniel Schneditż

Physiologisches Institut

Universität Graz

Harrachgasse 21/V

A-8010 Graz 